\title{
Cell Culture Systems for Assessing Toxicity and Chemotherapeutic Potential of Phytochemical Antioxidants
}

\author{
Peace C. Asuzu' ${ }^{1}$, Nicholas Trompeter ${ }^{2}$, Samuel A. Besong, ${ }^{1}$, Carlton R. Cooper ${ }^{3}$ and Alberta N.A. \\ Aryee $^{1^{*}}$
}

\author{
${ }^{1}$ Delaware State University, College of Agriculture, Science and Technology, Department of \\ Human Ecology (Food Science and Biotechnology Program), Dover, DE 19901 \\ ${ }^{2}$ University of Delaware, Department of Biomedical Engineering, Newark, DE 19716 \\ ${ }^{3}$ University of Delaware, Department of Biological Sciences, Center for Translational Cancer \\ Research, Newark, DE 19716 \\ * Correspondence: author e-mail: aaryee@desu.edu; Tel: +1302-857-6422
}

\begin{abstract}
This review article seeks to provide relevant information about the applicability of cell-based assays in assessing cytotoxicity of phytochemicals in light of several traditional methods available. Phenolic compounds and other phytochemicals are significant resources for drug discovery and development, thus underlining the enormous potentials of plant-derived natural products for the prevention and management of oxidative stress associated with cancer and other diseases. These effects have been linked to the content of phytochemicals such as phenolic compounds and their antioxidant properties. The abundance and complexity of these bio-constituents highlight the need for well-defined methods for the in vitro characterization and quantification of extracts and/or preparations that can translate to in vivo effects. Cell culture systems provide a useful model for basic research and a wide range of clinical in vitro studies and physiological processes as well as assessing the toxicity and therapeutic potential of compounds including plant extracts with potential medicinal benefits. Their use in cancer research provide a useful insight into possible therapeutic properties of phytochemicals at the cellular level. This approach has been instrumental in the initial stages of developing chemotherapeutic agents where human cancer cell lines are used as experimental models. These models have continued to contribute to elucidating specific requirements for certain biochemical events associated with proliferation, metabolism, loss of cell viability/apoptosis. Cell culture systems remain a promising tool in natural product development.
\end{abstract}

Keywords: Antioxidant activity; Reactive oxygen species; Medicinal plants; Cancer cell lines; Cytotoxicity

\subsection{INTRODUCTION}

Globally, cancer is a leading cause of death. It is among the top two causes of death prior to age 70 in 112 of 183 countries and third or fourth leading cause in a further 23 countries, according to World Health Organization (WHO) estimates in 2019 [1,2]. The rising prominence of cancer as a leading cause of death and a combination of factors such as constraints 
in availability of clinical interventions, and in access to and use of current technologies, have served to dampen the effects of treatment on population trends in cancer deaths, even in developed countries [3]. While combining screening and treatment has been shown to be progressively effective in reducing the number of fatalities from some cancers, an expected global cancer burden of 28.4 million cases in 2040, a rise of $47 \%$ from 2020 figures, necessitates the development of new tools with which to address the unmet needs in cancer management [1,2]. Even though newer, more specific treatments have shown promising results, they can be expensive, and more research is required to determine how to best use these drugs, as well as the toxicities associated with their use [4].

The most common types of cancer treatments available today are chemotherapy, surgery, and radiotherapy. Chemotherapy has been shown to lead to desired outcomes in subsets of patients presenting with advanced disease, such as small cell lung carcinoma, acute myelogenous and acute lymphoblastic leukemia, ovarian cancer, including Hodgkin's and nonHodgkin's lymphoma, choriocarcinoma, and, germ cell cancer. [5,6]. Chemotherapy has also been used as a neoadjuvant therapy, to reduce the size of solid tumors before surgical removal; as well as an adjuvant therapy, after surgery or radiotherapy, with promising results [6]. However, for some other advanced cancers, including prostate cancer, a curative treatment regimen is yet to be discovered [1]. Thus, the search for new therapies or new combinations of therapies for the improvement of cancer treatment outcomes has continued.

Increased reactive oxygen species (ROS) levels have been found in almost all cancers and are thought to play an important role in the initiation and progression of cancers [7]. These highly reactive ions and molecules are produced during normal metabolism of cells but are present in higher levels in cancer cells due to increased metabolism, mitochondrial dysfunction, the activity of peroxisomes, higher cellular receptor signaling, oncogene activity, increased enzymatic action of oxidases, cyclooxygenases, lipoxygenases and thymidine phosphorylase, or through crosstalk with infiltrating immune cells [7]. ROS are managed under normal physiological conditions, through detoxification by non-enzymatic molecules like glutathione or through antioxidant enzymes which specifically quench distinct types of ROS [7]. As a result, scientists have looked to plants, and continue to consider plants, which are natural sources of exogenous antioxidants, as possible sources of effective treatments for different cancers.

\subsection{Medicinal Plants in Cancer Treatment and Management}

For centuries, bioactive compounds from plants have been credited with various therapeutic functions including anticancer properties. Phytochemicals are classified as primary or secondary metabolites based on their role in plant metabolism [8]. Secondary metabolites are chemically active compounds including alkaloids, anthocyanins, flavonoids, terpenoids, tannins, steroids, saponins, coumarins, phenolics and antioxidants. These are often produced in response to stress, are more complex in structure, and are less widely distributed than the primary metabolites [8,9]. They are pharmacologically active as anti-oxidative, anti-allergic, anti-bacterial, antifungal, anti-diabetic, anti-inflammatory and anti-carcinogenic compounds 
[9-11]. It is common for a single plant to produce many secondary metabolites with a wide range of chemical and biological properties, providing a range for bioactive substances [11].

In the last decades, a considerable number of plants has been shown to possess chemo-preventive and therapeutic properties against various cancers [1,12-28], with the US National Cancer Institute reporting reproducible anticancer properties for about 3000 plants out of a total of 35,000 plant species screened for potential anticancer activities [29]. These studies show the effectiveness and synergistic effects of phytochemicals in plant extracts in various diseases [19,30,31]. Researchers have discovered that polyphenols are very good antioxidants capable of neutralizing the destructive reactivity of unwanted reactive oxygen/nitrogen species produced as byproducts in the course of the body's metabolic processes [32]. Also, results from epidemiological studies show that polyphenols provide a significant protection against the development of several chronic conditions such as cardiovascular diseases (CVDs), cancer, diabetes, infections, aging and asthma [32]. Phenolic phytochemicals are the largest category of phytochemicals and the most common in plants [33].

More than $60 \%$ of currently used anti-cancer agents are estimated to be derived from natural sources [19]. These include Prunus africana (Prunus africana (Hook.f.) Kalkman) or Pygeum africanum (Hook. f.) also known as African cherry, bitter almond, African prune, and red stinkwood. Apart from its use for timber, it is particularly useful as a medicinal plant, whose leaves, roots and bark are used in traditional medicine in Africa [1,19,34-37]. This is not surprising since various bioactive substances with anti-inflammatory, anti-cancer, and anti-viral properties have been found in various species of the genus Prunus $[35,36,38,39]$. Other plants with reproducible or potential anticancer properties include Tinospora cordifolia which contains alkaloids like columbin and has been shown to dose dependently kill HeLa cells, Ziziphus nummularia which contains Betulin and betulinic acid and have been shown to potentiate the anticarcinogenic properties of certain anticancer drugs, and Curcuma longa (curcumin) whose antiproliferative properties include the in vitro inhibition of tumor cell invasion and metastasis [29].

\subsection{Assessing Antioxidant Capacity}

There are numerous methods for phytochemical screening, with sometimes more than one test for a particular group of compounds. For instance, the Wagner and Dragendorff's tests and Borntrager's test for alkaloids and glycosides, the Shinoda test for flavonoids, the phenol test for phenols, the frothing or foam test for saponins, the Braemer's test for tannins, and the Salkowski test for terpenoids [40-43] all provide a simple, quick, and inexpensive way to determine the various types of phytochemicals in a mixture [41-43]. Immunoassays use monoclonal antibodies (MAbs) against low molecular weight natural bioactive compounds and are highly specific and sensitive for receptor binding analyses, enzyme assays, qualitative and quantitative analytical techniques. Enzyme-linked immunosorbent assays (ELISA) based on MAbs are more sensitive in many cases than conventional HPLC methods [43]. ELISA was utilized in the assay of forskolin, a labdane diterpenoid, isolated from Coleus forskohlii, which has been used in traditional medicine in the Indian subcontinent for centuries [44]. Forskolin was detected 
with a range of $0.003-5.97 \mu \mathrm{g} / \mathrm{mg}$ dry weight in different plant parts, showing that ELISA can be utilized to assay a wide range of forskolin contents. In the same study, ELISA was used to measure the contents of Ginsenoside $\mathrm{Rb} 1$ (GRb1), a major ginseng component. The authors compared their findings to reports of HPLC analysis of ginsenosides and concluded that for results obtained using ELISA and HPLC methods, there is a close correspondence in the range of concentrations found in the plant materials. In addition, ELISA was more sensitive than the TLC or HPLC methods and did not require pretreatment of crude extracts [44].

Researchers can identify the spectra of most unknown plant compounds by comparing them to a library of known compound spectra using Fourier transform infrared spectroscopy (FTIR), a valuable tool which can be used for the identification and characterization of compounds or functional groups present in an unknown mixture of plants extract. Plant samples for FTIR can be prepared in different ways: for liquid samples, it is easiest to place one drop of sample between two plates of $\mathrm{NaCl}$, which then forms a thin film between the plates (Reference needed). Solid samples can be combined with potassium bromide $(\mathrm{KBr})$ and compressed into a thin pellet for analysis or may be dissolved in a solvent like dichloromethane, placing the solution onto a single salt plate and evaporating the solvent, to leave behind a thin film of the original material on the plate [43]. FTIR was used in the identification of the different functional groups of annonaceous acetogenins, potent anticancer compounds, from both liquid and solid samples of soursop (Annona muricata $\mathrm{L}$ ) leaves and the compounds identified were confirmed using HPLC [45].

\subsubsection{Cell Culture}

Cells provide a useful model for studying and monitoring the progression of physiological processes, as well as assessing the toxicity and therapeutic potential of compounds of biogenic origin [46]. Researchers use cell culture systems for basic research and a wide range of clinical in vitro studies [47], testing the potency and cellular toxicity of plant extracts with potential medicinal benefits. This includes their use in cancer research, where cell cultures have provided insight into the biology of cancer cells, in addition to facilitating the testing of potential therapies for prevention and treatment [48]. One of the first measures in the development of chemotherapeutic agents involves determining their anti-cancer activity in vitro using human cancer cell lines as experimental models [49,50]. For instance, in a study of the chemotherapeutic potential of the PC3 human prostate cancer cell line of propolis, a natural, resinous hive product derived from the buds of poplar and cone-bearing trees, the polyphenolic compounds contained in an ethanolic extract of Egyptian propolis (EEP) showed potent antioxidant and antitumor activities which compared favourably with those of doxorubicin, an established chemotherapeutic drug [51]. In addition, EEP alone or in combination with doxorubicin showed stronger antioxidant, antiproliferative and apoptotic effects against PC3 cells compared to doxorubicin alone. In a similar study, an aqueous extract of Urtica dioica, a perennial herbaceous flowering plant was reported to demonstrate strong antioxidant and antiproliferative activities in MCF-7 breast cancer cell lines [52] as demonstrated by DNA fragmentation, the appearance of apoptotic 
cells in flow cytometry analysis and an increase of the amount of calpain 1, calpastatin, caspase 3, caspase 9, Bax and Bcl-2.

Cell culture techniques involve the removal of cells from a plant or animal and their subsequent cultivation in an artificially favorable environment [46]. The cells could be directly obtained from the tissue and then separated by enzymatic or mechanical means prior to cultivation, or they could be taken from a cell line or cell strain that has already been established. The in vitro cultivation of organs, tissues, and cells is collectively known as tissue culture, and has continued to be useful in various scientific fields $[53,54]$.

When cells isolated from tissues are grown under appropriate conditions and maintained until they reach confluence, the cells are referred to as a primary culture. They are then sub-cultured by transferring them to a new culture dish with fresh growth medium in order to allow space for continued growth. After the first sub-culture, the primary culture becomes known as a cell line or sub-clone [46,54]. Cell lines derived from primary cultures have a limited life span [46]. Cell lines can exist as adherent cultures or grow in "suspension." Most cell types will stick to a "substrate" like plastic or glass and proliferate as a monolayer, in contrast to suspension cultures, which do not adhere to a substrate and will grow floating in a medium [54]. Cell lines of normal tissue are finite because they divide only a limited number of times before losing their ability to proliferate. However, some cell lines become immortal through a process called transformation, which can either occur spontaneously or be chemically or virally induced by reactivating telomerase and inactivating the p53 and retinoblastoma (RB) tumor suppressor pathways $[46,55]$.

\subsubsection{Cancer Cell Lines}

Cancer cell lines are useful tools in life science research because they do not only provide a multifaceted model for studying the biological mechanisms of cancer progression, development and therapy, but some of them have also been used to study other physiological processes e.g. the use of the human colorectal adenocarcinoma cells as a model for studying the intestinal epithelial barrier, nutrient transport nutrient bioavailability. The use of cancer cell lines improved the understanding of deregulated genes and signaling pathways in disease, which is crucial to study of genetic, epigenetic and cellular pathways, of proliferation deregulation, apoptosis and cancer progression, to define potential molecular markers, and to screen and characterize cancer therapeutic agents [48]. Numerous cell lines with their unique properties and characteristics are currently available for in vitro study of different diseases, especially cancer [56].

For several reasons, the use of cell lines is particularly advantageous in cancer research. Cell lines are easy to handle and manipulate genetically/epigenetically by using demethylation agents, small interfering ribonucleic acid (siRNA), expression vectors, and can be pharmacologically manipulated through cytostatics (cell growth inhibitors). Cell lines are very homogenous providing a uniform population of tumor cells for easier analysis rather than the heterogeneous solid tumors. However, to imitate in vivo tumor characteristics as closely as possible, a cancer cell line panel representative of the heterogeneity observed in the primary tumors can be 
used. Cancer cell lines are pure populations of tumor cells and share many characteristics with the initial tumor, while being readily accessible to the scientific community. Because of this, results of experiments using correct conditions are easily reproducible [48]. In addition, there is a substantial number and variety of cancer cell lines available.

Despite these advantages, some disadvantages of using cancer cell lines include cross-contamination of cell lines with HeLa cells, genomic instability leading to differences between the original tumor and the specific cell line, changes in the morphology, gene expression, and cellular pathways of cell lines from culture conditions required to maintain them, and infections with mycoplasma [48]. Furthermore, it is difficult to establish long-term cancer cell lines of certain types of tumors including prostate cancer tumors $[48,55]$. The limited number of cell line models for prostate cancer research can be attributed to the challenges with growing prostate cancer cells in vitro for protracted periods. Many investigators have been able to generate only seven cell lines that were previously available through public cell line depositories, but these do not represent the entire range of clinical disease. New cell lines, which demonstrate the commonly observed clinical phenotypes, are clearly needed [55].

There are many prostate cancer cell lines in use today, most of which have been established from metastatic deposits [57]. The LNCaP cell line, isolated from a subclavian lymph node metastasis of prostate cancer, maintains several key markers such as prostate specific antigen (PSA), prostate specific membrane antigen (PSMA) and the androgen receptor (AR) [58]. Through passage and hormonal manipulation in vivo, the lineagerelated LNCaP sublines have resulted in a series of cells that mimic the progression of prostate cancer from the original androgen sensitive (AS) LNCaP cell line to the androgen-independent (AI) C4-2 and C4-2B cell lines $[58,59]$.

An AI cell line, C4-2, reproducibly and consistently follows the metastatic patterns of hormone-refractory prostate cancer by producing lymph node and bone metastases when injected either subcutaneously or orthotopically in either hormonally intact or castrated hosts [1]. This model enables the study of factors that determine the predilection of prostate cancer cells for the skeletal microenvironment [59]. These C4-2 cells have a doubling time of about $48 \mathrm{~h}$, are androgen independent, express an androgen receptor, metastasize to lymph nodes, and produce PSA [56,57]. The AI C4-2 cell line differs from its parent AS LNCaP, with differential expression of 38 genes between the two cell lines ( $\geq 2$-fold change, $95 \% \mathrm{CI}$ ), 14 of which expressed at higher levels in LNCaP than in C4-2 cells, while the remaining 24 were expressed at lower levels in LNCaP than in C4-2 cells. In addition, the AI C42 cell line is highly tumorigenic and metastatic, including spontaneous metastasis to bone, whereas the AS LNCaP cell line is only weakly tumorigenic and is non-metastatic [58].

Several cell lines have been used in anti-cancer bioassays of medicinal plants (Table 1). These phytochemicals were shown to induce apoptosis but inhibit proliferation/metabolism and certain enzyme activities due to their inherent antioxidant activities [1,17,25,39,60-65] (Figure 1). 
$1 \quad$ Table 1: Some cell lines for in vitro analysis of medicinal plants

\begin{tabular}{|c|c|c|c|c|c|}
\hline Cell line & Culture medium & Supplementation & Culture conditions & $\begin{array}{l}\text { Medicinal } \\
\text { plant }\end{array}$ & Reference \\
\hline $\begin{array}{l}\text { Androgen-dependent growing human prostate } \\
\text { cancer cell line, LNCaP (lymph node prostate } \\
\text { cancer) }\end{array}$ & $\begin{array}{l}\text { Roswell Park Memorial } \\
\text { Institute (RPMI) } 1640 \\
\text { medium }\end{array}$ & $\begin{array}{l}10 \% \text { fetal calf serum (FCS), penicillin (100 U/mL), } \\
\text { streptomycin }(100 \mathrm{U} / \mathrm{mL}) \text {, and } 25 \mathrm{mM} \mathrm{4-(2-hydroxyethyl)-} \\
\text { 1-piperazineethanesulfonic acid (HEPES) }\end{array}$ & $\begin{array}{l}5 \% \quad \mathrm{CO}_{2}-95 \% \quad \text { air, } \\
\text { humidified atmosphere at } \\
37^{\circ} \mathrm{C}\end{array}$ & Prunus africana & {$[60]$} \\
\hline $\begin{array}{l}\text { Human hepatoma Hep3B cells stably } \\
\text { expressing green fluorescent protein (GFP)- } \\
\text { AR or yellow fluorescent protein (YFP)-AR- } \\
\text { cyan fluorescent protein (CFP) }\end{array}$ & $\begin{array}{l}\text { Minimum Essential } \\
\text { Medium Eagle, alpha } \\
\text { modification (a-MEM) }\end{array}$ & $\begin{array}{l}5 \% \text { FCS, } 2 \mathrm{mM} \mathrm{L-glutamine,} \mathrm{penicillin}(100 \mathrm{U} / \mathrm{mL}) \text {, } \\
\text { streptomycin }(100 \mathrm{U} / \mathrm{mL}) \text {, and Genticin }(\mathrm{G} 418)\end{array}$ & $\begin{array}{l}5 \% \quad \mathrm{CO}_{2}-95 \% \quad \text { air, } \\
\text { humidified atmosphere at } \\
37^{\circ} \mathrm{C}\end{array}$ & Prunus africana & {$[60]$} \\
\hline Monkey kidney CV1 cells & $\begin{array}{lr}\text { Dulbecco's } & \text { modified } \\
\text { Eagle's } & \text { medium } \\
(\mathrm{DMEM}) & \\
\end{array}$ & $\begin{array}{l}10 \%(\mathrm{v} / \mathrm{v}) \mathrm{FCS} \text {, penicillin }(100 \mathrm{IU} / \mathrm{ml}) \text { and streptomycin } \\
(100 \mathrm{IU} / \mathrm{ml})\end{array}$ & $37^{\circ} \mathrm{C}$ and $5 \% \mathrm{CO}_{2}$ & Prunus africana & {$[39]$} \\
\hline $\begin{array}{l}\text { Mouse mammary breast cancer cell line, } \\
\text { mouse colon cancer cell line and Vero cells } \\
\text { (monkey kidney cells) }\end{array}$ & $\begin{array}{lr}\text { Earl's } & \text { Minimum } \\
\text { Essential } & \text { Media } \\
\text { (EMEM) } & \\
\end{array}$ & Penicillin, streptomycin and $10 \%$ fetal bovine serum (FBS) & $\begin{array}{l}37^{\circ} \mathrm{C} \text { in a humidified } \\
\text { atmosphere of } 5 \% \mathrm{CO}_{2}\end{array}$ & Prunus africana & {$[61]$} \\
\hline Human embryonic kidney cells, HEK293 & EMEM & $\begin{array}{l}\text { Glutamine, } 10 \% \text { FBS and antibiotics }(100 \mu \mathrm{g} / \mathrm{mL} \text { penicillin, } \\
100 \mu \mathrm{g} / \mathrm{mL} \text { streptomycin })\end{array}$ & $37^{\circ} \mathrm{C}$ in $5 \% \mathrm{CO}_{2}$ & $\begin{array}{l}\text { Moringa oleifera, } \\
\text { Prunus africana }\end{array}$ & {$[62]$} \\
\hline Colorectal adenocarcinoma cell line, Caco-2 & EMEM & Glutamine, $10 \%$ FBS and antibiotics & $37^{\circ} \mathrm{C}$ in $5 \% \mathrm{CO}_{2}$ & $\begin{array}{l}\text { Moringa oleifera, } \\
\text { Prunus africana }\end{array}$ & {$[62]$} \\
\hline Hepatocellular carcinoma cell line, HepG2 & EMEM & Glutamine, $10 \%$ FBS and antibiotics & $37^{\circ} \mathrm{C}$ in $5 \% \mathrm{CO}_{2}$ & $\begin{array}{l}\text { Moringa oleifera, } \\
\text { Prunus africana }\end{array}$ & {$[62]$} \\
\hline $\begin{array}{l}\text { HepG-2, Caco-2 and the non-cancer cell line } \\
\text { HEK293 }\end{array}$ & EMEM + glutamine & $\begin{array}{l}10 \% \text { FBS, } 100 \mu \mathrm{g} / \mathrm{mL} \text { penicillin and } 100 \mu \mathrm{g} / \mathrm{mL} \\
\text { streptomycin }\end{array}$ & $37^{\circ} \mathrm{C}$ and $5 \% \mathrm{CO}_{2}$ & Prunus africana & {$[66]$} \\
\hline Human prostate carcinoma $\mathrm{LNCaP}$ cells & RPMI-1640 medium & $\begin{array}{l}10 \%(\mathrm{v} / \mathrm{v}) \text { FCS, } 1 \%(\mathrm{v} / \mathrm{v}) \text { penicillin and streptomycin, } 1 \% \\
(\mathrm{v} / \mathrm{v}) \text { L-glutamin and } 1 \%(\mathrm{v} / \mathrm{v}) \text { sodium pyruvate }\end{array}$ & $\begin{array}{l}\begin{array}{l}\text { Humidified } \\
\text { incubator }\end{array} \\
\text { incul }\end{array}$ & Prunus africana & {$[63]$} \\
\hline $\begin{array}{l}\text { Human prostate carcinoma cell lines PC3, } \\
\text { PC3-ARwt }\end{array}$ & DMEM & $\begin{array}{l}10 \%(\mathrm{v} / \mathrm{v}) \text { FCS, } 1 \%(\mathrm{v} / \mathrm{v}) \text { penicillin and streptomycin, } 1 \% \\
(\mathrm{v} / \mathrm{v}) \mathrm{L}-\mathrm{glutamin}(\text { and } 600 \mu \mathrm{g} / \mathrm{ml} \text { geneticin for PC3- ARwt) }\end{array}$ & $\begin{array}{lll}\begin{array}{l}\text { Humidified } \\
\text { incubator }\end{array} & 5 \% \quad \mathrm{CO}_{2} \\
\end{array}$ & Prunus africana & {$[63]$} \\
\hline Human prostate cancer $\mathrm{C} 4-2$ cells & DMEM & $\begin{array}{l}10 \%(\mathrm{v} / \mathrm{v}) \mathrm{FCS}, 20 \% \mathrm{~F} 12,5 \mu \mathrm{g} / \mathrm{mL} \text { Insulin, } 13.6 \mathrm{pg} / \mathrm{mL} \mathrm{T} 3 \\
\left(3,3^{\prime}, 5 \text {-triiodo-L-thyronine sodium salt), } 5 \mu \mathrm{gg} / \mathrm{ml}\right. \\
\text { apotransferrin, } 0.25 \mu \mathrm{g} / \mathrm{ml} \text { Biotin, } 1 \%(\mathrm{v} / \mathrm{v}) \text { penicillin and } \\
\text { streptomycin }\end{array}$ & $\begin{array}{lll}\text { Humidified } & 5 \% & \mathrm{CO}_{2} \\
\text { incubator } & & \end{array}$ & Prunus africana & {$[63]$} \\
\hline $\begin{array}{l}\text { Cells removed directly from human prostate } \\
\text { cancer tissue }\end{array}$ & $\begin{array}{l}\text { Endothelial basal } \\
\text { medium MCDB } 131\end{array}$ & $\begin{array}{l}1 \times \mathrm{L} \text {-glutamine, } 5 \% \mathrm{FCS}, 1 \times \text { MEM vitamins solution, } 1 \times \\
\text { insulin-tranferrin-selenium liquid media supplement, and } \\
1 \%(\mathrm{v} / \mathrm{v}) \text { antimycotic/ antibiotic solution }\end{array}$ & - & Prunus africana & {$[64]$} \\
\hline
\end{tabular}




\begin{tabular}{|c|c|c|c|c|c|}
\hline $\begin{array}{l}\text { Madin-Darby canine kidney epithelial cell line } \\
\text { (MDCK cells) }\end{array}$ & DMEM & $1 \times$ L-glutamine, $5 \%$ FCS and $1 \%(\mathrm{v} / \mathrm{v})$ antibiotic solution & - & Prunus africana & {$[64]$} \\
\hline $\begin{array}{l}\text { Vero E6, CT 26-CL } 25 \text { colon cancer cells and } \\
\text { Hep2 throat cancer cells }\end{array}$ & MEM medium & $10 \%$ FBS, $1 \%$ L-glutamine and $1 \%$ antibiotic solution & $\begin{array}{l}\text { High } \\
\text { environment at } 37^{\circ} \mathrm{C} \text { and } \\
5 \% \mathrm{CO}_{2}\end{array}$ & Prunus africana & {$[65]$} \\
\hline $\begin{array}{l}\text { Human ileoceacal adenocarcinoma, HCT-8 } \\
\text { cell line }\end{array}$ & RPMI-1640 & $\begin{array}{l}10 \% \text { heat inactivated FBS, } 2 \mathrm{mM} \text { L-glutamine, } 50 \mu \mathrm{g} / \mathrm{mL} \text { of } \\
\text { penicillin-G, and } 50 \mu \mathrm{g} / \mathrm{mL} \text { of streptomycin sulfate }\end{array}$ & $37^{\circ} \mathrm{C}$ and $5 \% \mathrm{CO}_{2}$ & Moringa oleifera & {$[25]$} \\
\hline Human breast cancer, MDA-MB-231 cell line & DMEM & $\begin{array}{l}10 \% \text { heat inactivated FBS, } 2 \mathrm{mM} \text { L-glutamine, } 50 \mu \mathrm{g} / \mathrm{mL} \text { of } \\
\text { penicillin-G, and } 50 \mu \mathrm{g} / \mathrm{mL} \text { of streptomycin sulfate }\end{array}$ & $37^{\circ} \mathrm{C}$ and $5 \% \mathrm{CO}_{2}$ & Moringa oleifera & {$[25]$} \\
\hline Human B-lymphoblastoid cells, Raji & RPMI-1640 & $\begin{array}{l}10 \% \text { fetal calf serum }(\mathrm{FCS}) \text { containing n-butyric acid }(3 \mathrm{mM}) \\
\text { and teleocidin B-4 }(50 \mathrm{nM})\end{array}$ & $37^{\circ} \mathrm{C}$ and $5 \% \mathrm{CO}_{2}$ & Moringa oleifera & {$[17]$} \\
\hline C4-2 prostate cancer cell lines & RPMI-1640 & $\begin{array}{l}\text { Glutamine, } 10 \% \text { fetal bovine serum and antibiotics (100 } \\
\mu \mathrm{g} / \mathrm{mL} \text { penicillin, } 100 \mu \mathrm{g} / \mathrm{mL} \text { streptomycin) }\end{array}$ & $37^{\circ} \mathrm{C}$ and $5 \% \mathrm{CO}_{2}$ & Prunus africana & {$[1]$} \\
\hline
\end{tabular}




\subsubsection{Anti-cancer bioassays}

In vitro anti-cancer screening has long been used by researchers as a rapid tool in screening natural and synthetic compounds for drug development $[1,62]$. To assess preliminary anti-cancer activity in terms of cell viability, the 3-(4, 5-dimethylthiazol-2-yl)-2, 5-diphenyltetrazolium bromide (MTT) and 3-(4,5-dimethylthiazol-2-yl)-5-(3-carboxymethoxyphenyl)-2-(4sulfophenyl)-2H-tetrazolium (MTS) in vitro cytotoxicity assays are considered two of the most economic, reliable, and convenient methods $[62,67]$. This is based on their ease of use, accuracy, rapid indication of toxicity, sensitivity and specificity[67]. Both assays are whole cell toxicity assays that employ colorimetric methods for determining the number of viable cells based on mitochondrial dehydrogenase activity measurement and differ only in the reagent employed [67].

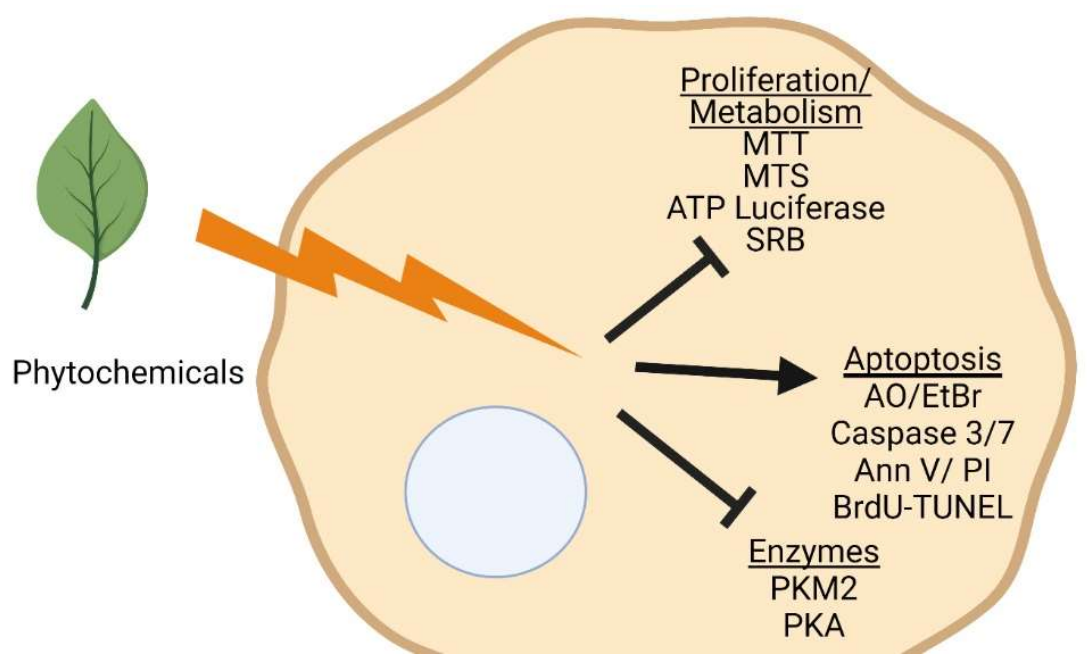

Figure 1. Anti-cancer bioassays to assess in vitro cellular effects of phytochemicals. The inherent antioxidant activities of phytochemicals may elicit anti-tumorigenic effects through either the inhibition of proliferation/cell metabolism, induction of cell apoptosis, or the inhibition of cancer-associated enzymes. Assays to assess each cellular function are listed below each underlined function. MTT: 3-(4, 5-dimethylthiazol-2-yl)-2, 5-diphenyltetrazolium bromide; MTS: 3-(4,5-dimethylthiazol-2-yl)-5-(3-carboxymethoxyphenyl)-2-(4-sulfophenyl)-2Htetrazolium; SRB: sulforhodamine B; AO/EtBr: Acridine orange/ethidium bromide; Ann V/PI: Annexin V/Propidium Iodide; BrdU-TUNEL: bromodeoxyuridineTerminal deoxynucleotidyl transferase-mediated d-UTP nick end labeling; PKM2: pyruvate kinase M2; PKA: protein kinase A. (Created with BioRender.com).

In the MTT assay, 3(4,5-dimethylthiazol-2-yl)-2,5-diphenyltetrazolium bromide is bio-reduced by dehydrogenase inside living cells using the succinate-tetrazolium reductase system, to form a colored formazan dye, while in the MTS assay, a similar bioconversion takes places using 3-(4,5dimethylthiazol-2-yl)-5-(3carboxymethoxyphenyl)-2-(4-sulfophenyl)-2Htetrazolium, inner salt and phenazine ethosulfate as an electron coupling reagent [62,67]. In addition, the MTT assay requires the addition of solubilizing agents to dissolve the insoluble formazan product, while the MTS assay generates a water-soluble formazan product that simplifies the 
assay. The number of viable cells is measured calorimetrically, based on the principle that the mitochondrial dehydrogenase enzymes which produce $\mathrm{NADH}$ or NADPH, reduce the colorless tetrazolium salt to a colored aqueous soluble formazan product through the mitochondrial activity of viable cells at $37^{\circ} \mathrm{C}$ [67]. The quantity of the colored product is directly proportional to the number of live cells in the culture since only metabolically active cells can reduce the MTT/MTS reagent to formazan $[62,67]$.

The MTT and MTS assays assess the toxicity of a compound to cells, not anti-cancer activity. When these assays are used, most researchers also screen for cytotoxicity to either mouse or human cancer cell lines and to normal cell lines such as peripheral blood lymphocytes, to determine how selective the compound is for cancer cells over normal cells. Although whole cell assays are important, further assays are required if the researcher wants to determine activity against a specific molecular or cellular target to confirm the mechanism of action, to assess the selectivity for different targets, and identify off-target effects. This can be achieved using in vitro inhibition assays with either purified enzymes or cell-free extracts enriched with the enzyme target of interest or apoptosis assays [67].

The sulforhodamine B (SRB) assay is a rapid, sensitive, and inexpensive method for determining cell growth, utilizing a bright pink anionic dye that binds electrostatically to basic amino acids of trichloroacetic acid fixed cells. The protein-bound dye is extracted with Tris (tris (hydroxymethyl) aminomethane) base to quantify the protein content indirectly with spectrophotometry [41]. The endpoint of the SRB assay is non-destructive, stable, and comparable with other fluorescence assays. However, it is labor intensive, requiring several washing steps [68,69].

A known characteristic of cancer cell growth and metastasis is the ability of the cells to escape apoptosis because of gene mutations in tumor suppressors. Induction of apoptosis is thus used as an important indicator of the ability of chemotherapeutic agents to inhibit tumor growth and progression, indicating the cancer cell line is sensitive to test compounds. The acridine orange/ethidium bromide (AO/EB) apoptosis assay is used to study changes in cellular and nuclear morphology and characteristics of apoptosis under a fluorescent microscope [62]. Both acridine orange and ethidium bromide bind to DNA and RNA by intercalation between adjacent base pairs, but acridine orange stains both live and dead cells while ethidium bromide stains dead cells only. Live cells appear green under the microscope and early apoptotic cells have a bright green nucleus due to chromatin condensation and nuclear fragmentation, while late apoptotic cells appear orange because they take up ethidium bromide, and necrotic cells will stain orange but have a normal nuclear morphology [62,70]. After cells are counted under the microscope an apoptotic index is calculated.

Another marker to measure cell membrane integrity, and thus cell apoptosis, is the Annexin V-FITC/propidium iodide (AnnV/PI) assay. During apoptosis and necrosis, transmembrane flippases translocate phosphatidylserine (PS) to the outer portion of the cell membrane, allowing AnnV to bind to this phospholipid [71]. As both apoptotic and necrotic cells display PS extracellularly, a cell exclusion dye is necessary to segregate between apoptotic and necrotic cells. PI is generally the cell exclusion dye of choice for the AnnV assay. PI stains the nuclei of late apoptotic cells 
undergoing blebbing, and for necrotic cells. Early apoptotic cells will be stained only with AnnV, while cells in the late stages of apoptosis stain for both AnnV and PI. Complete loss of the cell membrane integrity in necrotic cells culminates in these cells only staining for PI. Imaging for AnnV/PI staining can be completed either on a microscope or using a flow cytometer. Flow cytometric analysis of the AnnV/PI staining allows for sensitive and quick analysis of the number of viable, early apoptotic, late apoptotic, and necrotic cells. The AnnV/PI assay is often utilized to determine the cytotoxic effect of drugs on both health and cancer cell lines. Recently, a report highlighted the cytotoxic effect of phytochemicals from Allium sativum and Allium fjstolum on $\mathrm{HaCaT}$ cells (cultured human keratinocyte) and BJ fibroblastic cells (telomerase negative cell line derived from skin fibroblasts). High concentrations of extracts from these two plants induced necrosis in more than $10 \%$ of the populations analyzed [72].

While cell exclusion dyes can determine cell viability and apoptosis/necrosis, these assays fail to determine the apoptotic pathways activated during cytotoxicity and, namely caspases. Most anticancer mechanisms target caspases, as they are the proteolytic enzymes responsible for the initiation and execution of apoptosis [73]. Importantly, phytochemicals from Euphorbiaceae have been shown to activate the caspase 3/7 apoptotic pathway in A549, Caco-2,HeLa, and MCF-7 cancer cell lines [73]. Caspase $3 / 7$ activity was measured using tagged four-amino acid peptide (DEVD) that is conjugated to a fluorescently tagged nuclear binding dye. The DEVD peptide is cleaved by activated caspase 3/7 during apoptosis, which allows for the unbound fluorescent binding dye to interact with DNA within the nucleus. The advantage of some caspase 3/7 assays is the ability to stain live cells without needing to fix or lyse your cells. A pitfall to the caspase $3 / 7$ assay stems from the ability of natural flavonoids found in many phytochemicals to modulate and inhibit caspase 3 and 7 [74]. This suggests that the cytotoxic effect of flavonoids may be caspase independent.

The living status of a cell can be determined by measuring the amount of ATP in the cell, since ATP is necessary for life and function of all cells, and levels of cytoplasmic ATP decrease in cases of injury and hypoxia. After a cell is lysed, ATP is free to react with luciferin and luciferase, producing high quantum chemiluminescence, which is linearly proportional to the ATP concentration under optimum conditions. Compared to the MTT assay, the luciferase assay had higher sensitivity and reproducibility over several days and was able to detect the viability of cells with cell counts as low as 2000 cells/well compared to a minimum of 25,000 cells/well required for the MTT assay for above background readings [68]. The ATP assay was reported the most sensitive of the ATP, MTT and calcein assays, used to determine the potency of cytotoxic agents [75]. This high sensitivity of the ATP assay allowed for detection of cytotoxic agent-induced ATP breakdown after incubation periods as short as $1 \mathrm{~h}$, which provides an additional advantage over the MTT assay that requires approximately $72 \mathrm{~h}$ of incubation. A further advantage of the ATP assay was the short measurement time of $15 \mathrm{~s}$ per well, compared to the MTT assay which required a 1-2 $\mathrm{h}$ solubilization step of the formazan before an absorption measurement [75].

Enzymes are popular drug targets as they play a significant role in several disease processes and are susceptible to inhibition by small drug-like 
molecules. Pyruvate kinase isoenzyme M2 (PKM2) is a very significant regulatory enzyme functioning in the intracellular control of glucose consumption specific to cells with overgrowth tendency. Because inhibition and activation of this enzyme controls intracellular consumption of glucose, it is a good target for cancer treatment. In addition, PKM2 enzyme inhibition reduces metabolites, such as pyruvate and lactate, which are involved in drug resistance [76]. Another enzyme, cyclic adenosine monophosphate (c-AMP) dependent protein kinase A, regulates several physiological processes. The cAMP-protein kinase A (PKA) pathway has been linked to the promotion of malignant phenotypes of head and neck squamous cell carcinoma and was activated by a range of different tumors $[67,77]$. PKA inhibitors display both in vitro and in vivo anti-tumor activity against various human cancer cell lines, making the ability to selectively inhibit PKA a new way of potentially modulating cancer [67].

Many anticancer drugs used today inactivate target cells through the mechanism of apoptosis [78]. As one of the later steps in apoptosis, deoxyribonucleic acid (DNA) fragmentation, a process resulting from the activation of nucleases that break down DNA into small fragment, can be used as a measure of anticancer agent bioactivity [78]. When anticancer agents break down DNA, they expose many 3'-hydroxyl ends to which fluorescein deoxythymidine analog, 5-bromo-2'-deoxyuridine 5'-triphosphate (BrdUTP) molecules get attached, with the help of terminal deoxynucleotidyl transferase (TdT) [78]. After it is assimilated into the DNA, $\mathrm{BrdU}$ can be detected by an anti-BrdU antibody using standard immunohistochemical techniques, fluorescence microscopy or flow cytometry [78]. DNA fragmentation has been used in the evaluation of many anticancer compounds including derivatives of betulinic acid and botulin and 5-fluorouracil [78].

Some of the newer, more advanced test systems utilizing the above anticancer bioassays include modeling the tumor microenvironments. This is done with two-dimensional cultures, three-dimensional cultures, microfluidic systems, Boyden's chamber and models created using 3D bioprinting [79]. They have been developed to overcome some of the limitations of traditional cell culture test systems and are constantly evolving, as our understanding increases on the impact of various factors in the tumor microenvironment on cancer progression.

\section{Conclusion and outlook}

The increasing prevalence of cancers worldwide has made the development of quicker methods to create, develop, and test new anticancer drugs a necessity. Anticancer bioassays have proven to be powerful tools in the prescreening of interesting agents. However, caution should be exercised in comparing results from the different assays as they usually target different mechanisms. The choice of anti-cancer bioassay to use depends to a large extent on the researcher's objective, the target cancer cells and phytochemical composition of the medicinal plant, the availability of reagents and cost of reagents, as well as the experience of the research team. When interpreting results, researchers should be mindful of the hazards associated with cytotoxicity testing in general and of each assay format in particular. Cellbased anti-cancer bioassays have much to offer compared to animal testing. 
These assays are efficient, allow easy measurement of drug effects at the cellular level, and the results from these assays can be used to development models that predict the drug effect in animals.

Author Contributions: PA wrote primary manuscript; AA, SB, NT and CC edited the manuscript. All authors have read and approved this manuscript.

Funding: This study was supported by funding from USDA NIFA Evans-Allen (Project \# DELXHMEC2017).

Conflicts of Interest: The authors declare no conflict of interest.

\section{References}

1. Asuzu PC, Aryee ANA, Trompeter N, Mann Y, Besong SA, Duncan RL, Cooper CR: In Vitro Assessment of Efficacy and Cytotoxicity of Prunus africana Extracts on Prostate Cancer C4-2 Cells. bioRxiv 2021, doi:10.1101/2021.03.14.435338.

2. Sung H, Ferlay J, Siegel RL, Laversanne M, Soerjomataram I, Jemal A, Bray F: Global Cancer Statistics 2020: GLOBOCAN Estimates of Incidence and Mortality Worldwide for 36 Cancers in 185 Countries. CA Cancer J Clin 2021, 71:209-249.

3. Danaei G, Vander Hoorn S, Lopez AD, Murray CJ, Ezzati M: Causes of cancer in the world: comparative risk assessment of nine behavioural and environmental risk factors. Lancet 2005, 366:1784-1793.

4. Herbst RS, Bajorin DF, Bleiberg H, Blum D, Hao D, Johnson BE, Ozols RF, Demetri GD, Ganz PA, Kris MG, et al.: Clinical Cancer Advances 2005: Major research advances in cancer treatment, prevention, and screening - A report from the American Society of Clinical Oncology. J Clin Oncol 2006, 24:190-205.

5. Devita VT, Chu E: A History of Cancer Chemotherapy. 2008, doi:10.1158/0008-5472.CAN-07-6611.

6. Arruebo M, Vilaboa N, Sáez-Gutierrez B, Lambea J, Tres A, Valladares M, González-Fernández Á: Assessment of the Evolution of Cancer Treatment Therapies. Cancers (Basel) 2011, 3:3279-3330.

7. Liou G-Y, Storz P: Reactive oxygen species in cancer. Free Radic Res 2010, 44:479-496.

8. Krishnaiah D, Sarbatly R, Bono A: Phytochemical antioxidants for health and medicine - A move towards nature. Biotechnol Mol Biol Rev 2007, 1:97-104.

9. Kumari P, Kumari C, Singh PS: Phytochemical screening of selected medicinal plants for secondary metabolites. Int J Life- Sci Sci Res 2017, 3:1151-1157.

10. Gupta A, Naraniwal M, Kothari V: Modern extraction methods for preparation of bioactive plant extracts. Int J Appl Nat Sci 2012, 1:8-26.

11. Ncube A., Afolayan A., Okoh A.: Assessment techniques of antimicrobial properties of natural compounds of plant origin: current methods and future trends. African J Biotechnol 2008, 7:1797-1806.

12. Patel Subhashchandra, Patel Tushar, Parmar Kaushal, Bhatt Yagnesh, Patel Yogesh PNM: Isolation, characterization and antimicrobial activity of charantin from momordica charantia linn. fruit. Int J Drug Dev Res 2009, 2.

13. Jansakul, C; Wun-noi, A; Croft, K; Byrne L: Pharmacological studies of Thiocarbamate Glycosides Isolated from Moringa oleifera. J Sci Soc Thailand 1997, 23:335-346.

14. Gilani AH, Aftab K, Suria A, Siddiqui S, Salem R, Siddiqui BS, Faizi S: Pharmacological studies on hypotensive and spasmolytic activities of pure compounds fromMoringa oleifera. Phyther Res 1994, 8:87-91.

15. Bijina B, Chellappan S, Basheer SM, Elyas KK, Bahkali AH, Chandrasekaran M: Protease inhibitor from Moringa oleifera leaves: Isolation, purification, and characterization. Process Biochem 2011, 46:2291-2300.

16. Lo HY, Ho TY, Lin C, Li CC, Hsiang CY: Momordica charantia and its novel polypeptide regulate glucose homeostasis in mice via binding to insulin receptor. In Journal of Agricultural and Food Chemistry. . 2013:24612468.

17. Murakami A, Kitazono Y, Jiwajinda S, Koshimizu K, Ohigashi H: Niaziminin, a thiocarbamate from the leaves of Moringa oleifera, holds a strict structural requirement for inhibition of tumor-promoter-induced epsteinbarr virus activation. Planta Med 1998, 64:319-323.

18. Barbieri L, Zamboni M, Lorenzoni E, Montanaro L, Sperti S, Stirpe F: Inhibition of protein synthesis in vitro by proteins from the seeds of Momordica charantia (bitter pear melon). Biochem J 2015, 186:443-452.

19. Komakech R, Kang Y, Lee J, Omujal F: A review of the potential of phytochemicals from Prunus africana (Hook f.) Kalkman stem bark for chemoprevention and chemotherapy of prostate cancer. Evidence-Based Complement Altern Med 2017, 2017:1-10. 
20. Albuquerque Costa R, Sousa OV de, Hofer E, Mafezoli J, Barbosa FG, Vieira RHS dos F: Thiocarbamates from Moringa oleifera seeds bioactive against virulent and multidrug-resistant Vibrio species. Biomed Res Int 2017, 2017:1-6.

21. Eweka AO, Om'Iniabohs FAE, Momodu O: The histological effects of mixed diet containing Pausinystalia yohimbe ground stem bark on the kidney of adult Wistar rats (Rattus norvegicus). Biol Med 2010, 2:30-36.

22. Shenouda N, Sakla M, Newton L, Besch-Williford C, Greenberg N, MacDonald R, Lubahn D: Phytosterol Pygeum africanum regulates prostate cancer in vitro and in vivo. Endocrine 2007, 31:72-81.

23. Igwe K., Madubuike A., Ikenga C, Otuokere I., Amaku F.: Studies of the medicinal plant Pausinystalia yohimbe ethanol leaf extract phytocomponents by GCMS analysis. Int J Sci Res Manag 2016, 4:4116-4122.

24. Morales A: Yohimbine in erectile dysfunction: The facts. Int J Impot Res 2000, 12:S70-S74.

25. Al-Asmari AK, Albalawi SM, Athar MT, Khan AQ, Al-Shahrani H, Islam M: Moringa oleifera as an AntiCancer Agent against Breast and Colorectal Cancer Cell Lines. PLoS One 2015, 10:e0135814.

26. Chen J-C, Liu W-Q, Lu L, Qiu M-H, Zheng Y-T, Yang L-M, Zhang X-M, Zhou L, Li Z-R: Kuguacins F-S, cucurbitane triterpenoids from Momordica charantia. Phytochemistry 2009, 70:133-140.

27. Lee-Huang S, Huang PL, Nara PL, Chen HC, Kung H fu, Huang P, Huang HI, Huang PL: MAP 30: a new inhibitor of HIV-1 infection and replication. FEBS Lett 1990, 272:12-18.

28. Xiong SD, Yu K, Liu XH, Yin LH, Kirschenbaum A, Yao S, Narla G, DiFeo A, Wu JB, Yuan Y, et al.: Ribosomeinactivating proteins isolated from dietary bitter melon induce apoptosis and inhibit histone deacetylase-1 selectively in premalignant and malignant prostate cancer cells. Int J Cancer 2009, 125:774-782.

29. Desai AG, Qazi GN, Ganju RK, El-Tamer M, Singh J, Saxena AK, Bedi YS, Taneja SC, Bhat HK: Medicinal plants and cancer chemoprevention. Curr Drug Metab 2008, 9:581-591.

30. Karan M, Kumar Jena A, Sharma N, Vasisht K, Efferth T: A systematic analysis of Prunus species with a focus on management plan of Prunus africana (Hook.f.) Kalkman: An autochthon plant of Africa. European J Med Plants 2017, 20:1-24.

31. Nyamai D, Mawia A, Wambua F, Njoroge A, Matheri F, Lagat R, Kiambi J, Ogola P, Arika W, Cheseto X, et al.: Phytochemical profile of Prunus africana stem bark from Kenya. J Pharmacogn Nat Prod 2015, 1:1-8.

32. Pandey KB, Rizvi SI: Plant polyphenols as dietary antioxidants in human health and disease. Oxid Med Cell Longev 2009, 2:270-278.

33. Saxena M, Saxena J, Nema R, Singh D, Gupta A: Phytochemistry of medicinal plants. J Pharmacogn Phytochem 2013, 1:168-182.

34. Das S: Antibacterial activity of Prunus africana stem bark extract against Shigella spp. World J Pharm Pharm Sci 2017, doi:10.20959/wjpps20179-9979.

35. Jeruto P, Mutai C, Catherine L, Ouma G: Phytochemical constituents of some medicinal plants. J Anim Plant Sci 2011, 9:1201-1210.

36. Ngule MC, Ndiku MH, Ramesh F: Chemical constituents screening and in vitro antibacterial assessment of Prunus africana bark hydromethanolic extract. J Nat Sci Res 2014, 4:85-90.

37. Madivoli ES, Maina EG, Kairigo PK, Murigi MK, Ogilo JK, Nyangau JO, Kimani PK, Kipyegon C, Madivoli E: In vitro antioxidant and antimicrobial activity of Prunus africana ( Hook . $f$.) Kalkman ( bark extracts ) and Harrisonia abyssinica Oliv . extracts ( bark extracts ): A comparative study. J Med Plants Econ Dev 2018, 2:19.

38. Kadu C, Parich A, Schueler S, Konrad H, Muluvi GM, Eyog-Matig O, Muchugi A, Williams VL, Ramamonjisoa L, Kapinga C, et al.: Bioactive constituents in Prunus africana: Geographical variation throughout Africa and associations with environmental and genetic parameters. Phytochemistry 2012, 83:70-78.

39. Schleich S, Papaioannou M, Baniahmad A, Matusch R: Extracts from Pygeum africanum and other ethnobotanical species with antiandrogenic activity. Planta Med 2006, 72:807-813.

40. Edeoga HO, Okwu DE, Mbaebie BO: Phytochemical constituents of some Nigerian medicinal plants. African J Biotechnol 2005, 4:685-688.

41. Kumar G, Jayaveera K, Ashok Kumar C, Sanjay UP, Vrushabendra Swamy B, Kishore Kumar D, Sree Vidyanikethan A, Trop Pharm Res al J: Antimicrobial effects of Indian medicinal plants against acneinducing bacteria. Trop J Pharm Res 2007, 6:717-723.

42. Parekh J, Karathia N, Chanda S: Evaluation of antibacterial activity and phytochemical analysis of Bauhinia variegata 1. bark. African J Biomed Res 2009, 9:53-56.

43. Sasidharan S, Chen Y, Saravanan D, Sundram KM, Yoga Latha L: Extraction, isolation and characterization of bioactive compounds from plants' extracts. African J Tradit Complement Altern Med 2011, doi:10.4314/ajtcam.v8i1.60483.

44. Shoyama Y, Tanaka H, Fukuda N: Monoclonal antibodies against naturally occurring bioactive compounds. 
Cytotechnology 1999, 31:9-27.

45. Nik Mat Daud NNN, Ya'akob H, Mohamad Rosdi MN: Acetogenins of Annona muricata leaves: Characterization and potential anticancer study. Integr Cancer Sci Ther 2016, 3.

46. Invitrogen: Cell Culture Basics Handbook. ThermoFisher Sci Inc 2010, doi:10.1093/chemse/bjt099.

47. Goodspeed A, Heiser LM, Gray JW, Costello JC: Tumor-derived cell lines as molecular models of cancer pharmacogenomics. Mol Cancer Res 2016, 14:3-13.

48. Ferreira D, Adega F, Chaves R: The Importance of Cancer Cell Lines as in vitro Models in Cancer Methylome Analysis and Anticancer Drugs Testing. In Oncogenomics and Cancer Proteomics - Novel Approaches in Biomarkers Discovery and Therapeutic Targets in Cancer. . 2013:139-166.

49. Lovitt C, Shelper T, Avery V: Advanced cell culture techniques for cancer drug discovery. Biology (Basel) 2014, 3:345-367.

50. Wright Muelas M, Ortega F, Breitling R, Bendtsen C, Westerhoff H V.: Rational cell culture optimization enhances experimental reproducibility in cancer cells. Sci Rep 2018, 8:3029.

51. Salim EI, Abd El-Magid AD, Farara KM, Maria DS: Antitumoral and Antioxidant Potential of Egyptian Propolis Against the PC3 Prostate Cancer Cell Line. Asian Pacific J Cancer Prev 2015, 16:7641-7651.

52. Fattahi S, Ardekani AM, Zabihi E, Abedian Z, Mostafazadeh A, Pourbagher R, Akhavan-Niaki H.: Antioxidant and Apoptotic Effects of an Aqueous Extract of Urtica dioica on the MCF-7 Human Breast Cancer Cell Line. Asian Pacific J Cancer Prev 2013, 14:5317-5323.

53. Unchern S: Basic techniques in animal cell culture. Drug Deliv Work 1999,

54. Langdon S, Macleod K: Introduction to cancer cell culture. In Cancer Cell Culture-Methods and Protocols. Edited by Simon P. Langdon JMW. Humana Press Inc; 2011:1-791.

55. Vela I, Chen Y: Prostate cancer organoids: A potential new tool for testing drug sensitivity. Expert Rev Anticancer Ther 2015, 15:261-263.

56. Cunningham D, You Z: In vitro and in vivo model systems used in prostate cancer research. J Biol Methods 2015, 2:e17.

57. Russell PJ, Kingsley EA: Human prostate cancer cell lines. In Prostate Cancer Methods and Protocols. Edited by Russell P., Jackson P, Kingsley E. Humana Press; 2003:21-40.

58. Chen Q, Watson JT, Marengo SR, Decker KS, Coleman I, Nelson PS, Sikes RA: Gene expression in the LNCaP human prostate cancer progression model: Progression associated expression in vitro corresponds to expression changes associated with prostate cancer progression in vivo. Cancer Lett 2006, 244:274-288.

59. Thalmann GN, Sikes RA, Wu TT, Degeorges A, Chang SM, Ozen M, Pathak S, Chung LWK: LNCaP progression model of human prostate cancer: Androgen-independence and osseous metastasis. Prostate 2000, 44:91-103.

60. Hessenkemper W, Roediger J, Bartsch S, Houtsmuller AB, van Royen ME, Petersen I, Grimm M-O, Baniahmad A: A natural androgen receptor antagonist induces cellular senescence in prostate cancer cells. Mol Endocrinol 2014, 28:1831-1840.

61. Nabende P, Karanja S, Mwatha J, Wachira S: Anti-proliferative activity of Prunus africana, Warburgia stuhlmannii and Maytenus senegalensis extracts in breast and colon cancer cell lines. European J Med Plants 2015, 5:366-376.

62. Chepkoech MF: Phytochemistry and anti-cancer potential of compounds isolated from Kenyan medicinal plants , Moringa oleifera and Prunus africana. 2014,

63. Papaioannou M, Schleich S, Prade I, Degen S, Roell D, Schubert U, Tanner T, Claessens F, Matusch R, Baniahmad A: The natural compound atraric acid is an antagonist of the human androgen receptor inhibiting cellular invasiveness and prostate cancer cell growth. J Cell Mol Med 2009, 13:2210-2223.

64. Boulbès D, Soustelle L, Costa P, Haddoum M, Bali JP, Hollande F, Magous R: Pygeum africanum extract inhibits proliferation of human cultured prostatic fibroblasts and myofibroblasts. BJU Int 2006, 98:11061113.

65. Yiaile AL: In vitro antiploriferative activity, phytochemical composition and toxicity studies of Fagaropsis angolensis and Prunus africana crude extracts. 2017,

66. Maiyo F, Moodley R, Singh M: Phytochemistry, cytotoxicity and apoptosis studies of B-sitosterol-3oglucoside and B -amyrin from prunus Africana. African J Tradit Complement Altern Med 2016, 13:105-112.

67. McCauley J, Zivanovic A, Skropeta D: Bioassays for anticancer activities. Methods Mol Biol 2013, 1055:191-205.

68. Kumar S, Bajaj S, Bodla R: Preclinical screening methods in cancer. Indian J Pharmacol 2016, 48:481.

69. Vichai V, Kirtikara K: Sulforhodamine B colorimetric assay for cytotoxicity screening. Nat Protoc 2006, 1:11121116.

70. Liu K, Liu P, Liu R, Wu X: Dual AO/EB staining to detect apoptosis in osteosarcoma cells compared with 
flow cytometry. Med Sci Monit Basic Res 2015, 21:15-20.

71. Vermes I, Haanen C, Steffens-Nakken H, Reutellingsperger C: A novel assay for apoptosis Flow cytometric detection of phosphatidylserine expression on early apoptotic cells using fluorescein labelled Annexin V. J Immunol Methods 1995, 184:39-51.

72. Țigu AB, Moldovan CS, Toma V-A, Farcaș AD, Moț AC, Jurj A, Fischer-Fodor E, Mircea C, Pârvu M: Phytochemical Analysis and In Vitro Effects of Allium fistulosum L. and Allium sativum L. Extracts on Human Normal and Tumor Cell Lines: A Comparative Study. Molecules 2021, 26:574.

73. Mfotie Njoya E, Eloff JN, McGaw LJ: Croton gratissimus leaf extracts inhibit cancer cell growth by inducing caspase $3 / 7$ activation with additional anti-inflammatory and antioxidant activities. BMC Complement Altern Med 2018, 18:305.

74. White JB, Beckford J, Yadegarynia S, Ngo N, Lialiutska T, d'Alarcao M: Some natural flavonoids are competitive inhibitors of Caspase-1, $\mathbf{- 3}$ and -7 despite their cellular toxicity. Food Chem 2012, 131:1453-1459.

75. Mueller H, Kassack MU, Wiese M: Comparison of the usefulness of the MTT, ATP, and calcein assays to predict the potency of cytotoxic agents in various human cancer cell lines. J Biomol Screen 2004, 9:506-515.

76. Aslan E, Guler C, Adem S: In vitro effects of some flavonoids and phenolic acids on human pyruvate kinase isoenzyme M2. J Enzyme Inhib Med Chem 2016, 31:314-317.

77. Iqbal J, Abbasi BA, Mahmood T, Kanwal S, Ali B, Shah SA, Khalil AT: Plant-derived anticancer agents: A green anticancer approach. Asian Pac J Trop Biomed 2017, 7:1129-1150.

78. Moorthi C, Kathiresan K, Krishnan K, Manavalan R: In-vitro Cell Based Assay : A Preferred Anticancer Drug Screening Techniques for The Academic Researchers. J Pharm Res 2011, 4:671-675.

79. Kitaeva K V, Rutland CS, Rizvanov AA, Solovyeva V V: Cell Culture Based in vitro Test Systems for Anticancer Drug Screening. Front Bioeng Biotechnol 2020, 8:322. 